\title{
A MACRO-ECONOMIC INDICATOR OF AGE AT RETIREMENT
}

\author{
Robert L. Brown, ${ }^{*}$ Robin Damm, ${ }^{\dagger}$ Ishmael Sharara
}

\begin{abstract}
This paper explores the relationship between the Wealth Transfer Index (WTI), a statistic defined by Brown and Bilodeau (1997), and retirement age, which is the age at which the workers in an economy cease to be economically productive. A ppropriately expressed as ratio of consumption demand to labour productivity, WTI is a barometer for the demand for wealth placed on the workers of an economy. This paper explains why a relationship between this statistic and retirement age must exist. Using Canadian historical median retirement age data compiled by Statistics Canada and calculated values of the WTI for the same period, three linear regression models are fit. The conclusion from this analysis is that there is a strong positive correlation between the WTI and average retirement age.

This paper also briefly looks at the well-documented demographic shift expected to occur in Canada due to the baby-boom-baby-bust tidal wave. The aged dependency ratio is expected to increase dramatically, reaching $45 \%$ in 2036 . A practical application of the WTI model suggests that the baby boom cohort may experience a rise in the normal retirement age in the period 2017-2034. They will, in effect, be forced to retire at ages that will allow for an "acceptable" transfer of wealth from the workers to dependent Canadians. Using one of the fitted linear regression models, and projected values of the WTI, the paper then projects the median retirement age to 2041, for Canadian workers. The paper concludes by speculating on how the marketplace might respond to higher retirement ages.
\end{abstract}

\footnotetext{
* Robert L. Brown, Ph.D F.S.A., F.C.I.A., A.C.A.S., is Professor in the Department of Statistics and Actuarial Science, University of Waterloo, Waterloo On Canada N2L 3G1, e-mail,:

rlbrown@uwaterloo.ca.

${ }^{\dagger}$ Robin Damm, MMath is an Actuarial Associate at Towers Perrin, 150 Sixth Ave. SW, Suite 3700, Calgary, AB T2P 3Y7, Canada, e-mail: dammr@towers.com

${ }^{\ddagger}$ Ishmael Sharar, Mmath, A.S.A., is with Hewitt Associates, 25 Sheppard Ave. West, Toronto, ON M2N 6T1, Canada, e-mail: I2sharar@ hewitt.com.
} 


\section{INTRODUCTION}

In an economy it is the labour force that produces the goods and services demanded by consumers, both productive and unproductive. Through large-scale macro-economic wealth transfer schemes such as social security, education, unemployment insurance and national health care, wealth is redistributed from the workers to the beneficiaries of these schemes. The redistribution is accomplished by means of the sale of assets by retirees (e.g. pension asset liquidation), taxes on the worker's earnings, social security contributions, charitable donations, and voluntary altruism.

Brown (1999) argues that there is a limit on the demand for wealth transfer that can be borne by the workers in an economy. He maintains that the economy has 'self-adjusting' mechanisms (acting through the government, employers, individuals, or economic forces), that always ensure that at any given time, only an 'acceptable' demand for wealth by dependants can be placed on workers. One way to maintain an acceptable balance is a shift in the average age at which a worker retires (i.e. ceases to be economically productive). Workers will retire at the earliest age that is " affordable" in a macro-economic sense.

This paper attempts to validate this argument by using a statistic called the Wealth Transfer Index (WTI), which measures the relative demand for wealth placed on the labour force by youth, unemployed and aged. Using Canadian data, we show that a strong positive correlation between the WTI and average retirement age does in fact exist, thus supporting the hypothesis that the average retirement age of a given population will shift to allow for a stable wealth transfer from the workforce to all dependent Canadians. The paper concludes by projecting the average age at retirement for the Canadian working population for years to 2041, using historical retirement age data from Statistics Canada, average rates of productivity improvement and forecasted values of the WTI for years to 2041.

\section{The Wealth Transfer Index (WTI)}

The WTI, developed by Brown and Bilodeau (1997), is a statistic that measures the relative supply of and demand for wealth among the Canadian population. It is defined as:

$$
W T I=\frac{[(1.866 \times Y)+(1 \times U)+(4.636 \times A)]}{L F}
$$

where $\mathrm{Y}=$ Youth, 0-19

$\mathrm{U}=$ Unemployed adults

A $=$ Aged, 65 and over

LF $=$ The Employed Labour Force aged 20-64

The weights of 1.866, 1, and 4.636 were derived by McDonald and Carty (1980, pp.16-17) for the Task Force on Retirement Income Policy (1979) and depict relative wealth transfer weights for the young, unemployed adults, and the elderly, respectively. The weights do not have any meaning by themselvesthey are only weights relative to a weight of "1" for unemployed adults. It is important to note that the transfers to the aged are almost exactly 2.5 times the transfers to youth. These weights are based on total payments for health care, education, unemployment transfers, and retirement income security made by any government (federal, provincial or municipal). While this does not represent the totality of dependency costs, it does capture the key macro-economic indicators. It should be noted that a factor for productivity improvement should be included in the denominator for comparisons of wealth transfers over a period of years. For example, even if the demand for goods and services by dependants were to grow, the increased demand for wealth transfer could be met if the work force became more productive.

There are problems with the use of this index as is. First, the study on which the weights are derived is now 20 years old. It is true that in 1982 Foot (1982, p. 135) corroborated the weights (and suggested that in the United States, the ratio of transfers to the aged would be about three times the transfers to youth), but no later data exist. There are many reasons that over that 20 -year time span the weights would have shifted. Educating the young has become more expensive, as has health care for the elderly. Some social security payments (e.g. Old Age Security and the Guaranteed Income Supplement) are indexed to inflation, while others (e.g. the Canada/Quebec Pension Plans) are indexed (prior to retirement) to wages. Further, ad hoc amendments to all of these plans have taken place over this 20 -year period. At the end of 
the day, however, these data are all that are available. Thus, we argue that we should continue the study as outlined.

\section{Canada: Demographics and Implications for the future}

The Canadian Baby Boom-Baby Bust demographic profile has been well documented. The rise in birth rates during the 1950's and early 1960's coupled with the dramatic decline in these rates in the 1970's will shift the population age structure over the coming years. Exacerbating the rise in the number of seniors in Canada is the fact that life expectancy is increasing (see Table 1). Figure 1 outlines the historical and projected distribution of youth, adult and aged in Canada up to 2100. Clearly, this "aging" of the population will create a heavy demand for wealth transfer from the workers to the elderly, which could create pressure for an increase in taxes and other contributions from the workers' earnings, all else being equal.

However, this shift could mean that baby boomers will simply not be able to retire at the ages currently accepted as the norm. There are several reasons why this might come true. Assume that the massive baby boom cohort attempted to retire at ages now accepted as normal. As the baby boomers attempted to liquidate their assets, to buy goods and services, these asset prices could become depressed.

Table 1

Life Expectancy in Canada (1931 to 1994)*

\begin{tabular}{|c|c|c|c|c|c|c|}
\hline \multirow[b]{2}{*}{ Year } & \multicolumn{2}{|c|}{ At birth } & \multicolumn{2}{|c|}{ At age 65} & \multicolumn{2}{|c|}{ At age 75} \\
\hline & Male & Female & $\overline{\text { Male }}$ & Female & $\overline{\text { Male }}$ & Female \\
\hline 1931 & 60.0 & 62.1 & 13.0 & 13.7 & 7.6 & 8.0 \\
\hline 1951 & 66.3 & 70.8 & 13.3 & 15.0 & 7.9 & 8.8 \\
\hline 1971 & 69.3 & 76.4 & 13.7 & 17.5 & 8.5 & 10.7 \\
\hline 1991 & 74.6 & 80.9 & 15.7 & 19.9 & 9.6 & 12.5 \\
\hline 1994 & 75.1 & 81.1 & 16.1 & 20.1 & 9.9 & 12.7 \\
\hline
\end{tabular}

*These are period life expectancies based on the q's experienced in the reference year, without projection.

Source: Statistics Canada, 1986, 1995a, 1997

Figure 1

Distribution of Historical and Projected Population by Age Group

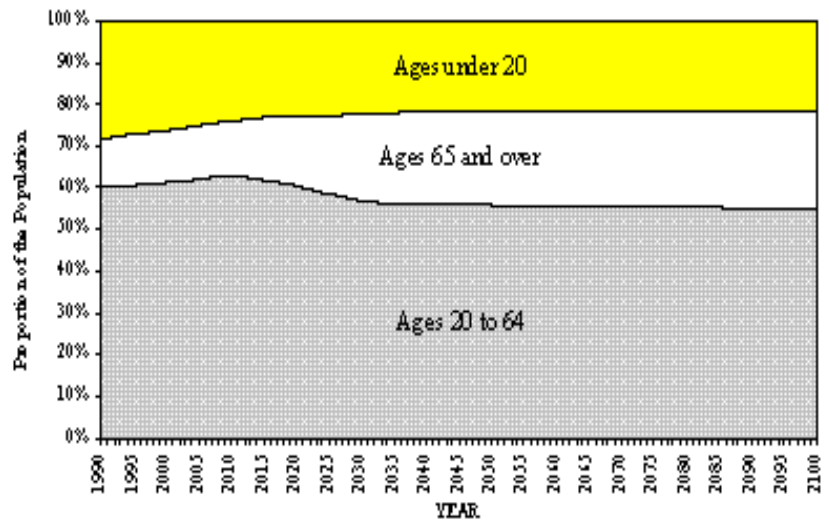

Source: Office of the Superintendent of Financial Institutions, 1998

Furthermore, because the much smaller baby bust generation is now the only source of labour, production in the economy could suffer a slump, whilst demand for consumption goods and services remains level. The expected result would be price inflation.

To the extent that the retirement decision is dependent on the real value of assets accumulated versus the current cost of goods and services, then it is clear that some baby boomers might be forced to postpone their exit from the workforce (see also Schieber and Shoven 1994). Employers, as well as governments, would also be expected to provide incentives for later retirement because there would be a decline in the supply of labour (Statistics Canada, 1996, p. 39). In other words, the baby boomers might 
be forced to adjust to new ages of retirement that would continue to allow a constant wealth transfer from a stable work force to all dependent Canadians.

\section{Analysis of the Wealth Transfer Index versus the Historic Retirement Age}

Table 2 gives calculated values for the WTI based on data for the years 1976-1998, yearly productivity improvements for the same period, and median retirement ages for Canada for the years 1976-1995 (Statistics Canada, 1999). Statistics Canada has published data on age of retirement only since 1976, so no earlier periods could be analyzed.

A linear regression model of the average retirement age was fitted against the WTI, adjusted for annual labour productivity improvements (see Figure 2).

Table 2

\section{Median Retirement Age and Wealth Transfer Index (Adjusted and Unadjusted) for 1976 - 1998}

\begin{tabular}{|c|c|c|c|c|}
\hline Year & MRA & $\begin{array}{c}\text { Productivity } \\
\text { increase }\end{array}$ & WTI & $\begin{array}{c}\text { WTI- } \\
\text { Adjusted }\end{array}$ \\
\hline 1976 & 65.00 & $1.89 \%$ & 2.962 & 2.962 \\
\hline 1977 & 64.92 & $0.00 \%$ & 2.927 & 2.872 \\
\hline 1978 & 65.00 & $0.00 \%$ & 2.847 & 2.793 \\
\hline 1979 & 64.92 & $0.46 \%$ & 2.747 & 2.696 \\
\hline 1980 & 64.83 & $0.00 \%$ & 2.684 & 2.622 \\
\hline 1981 & 64.92 & $0.92 \%$ & 2.617 & 2.556 \\
\hline 1982 & 64.83 & $2.28 \%$ & 2.721 & 2.633 \\
\hline 1983 & 64.67 & $3.13 \%$ & 2.708 & 2.559 \\
\hline 1984 & 64.75 & $1.73 \%$ & 2.639 & 2.413 \\
\hline 1985 & 64.67 & $-0.43 \%$ & 2.571 & 2.307 \\
\hline 1986 & 64.58 & $0.43 \%$ & 2.515 & 2.267 \\
\hline 1987 & 63.25 & $0.00 \%$ & 2.488 & 2.232 \\
\hline 1988 & 63.83 & $0.00 \%$ & 2.443 & 2.192 \\
\hline 1989 & 63.33 & $0.43 \%$ & 2.441 & 2.190 \\
\hline 1990 & 62.92 & $0.85 \%$ & 2.475 & 2.210 \\
\hline 1991 & 62.58 & $1.68 \%$ & 2.582 & 2.284 \\
\hline 1992 & 62.33 & $0.41 \%$ & 2.636 & 2.289 \\
\hline 1993 & 61.83 & $1.65 \%$ & 2.632 & 2.274 \\
\hline 1994 & 62.33 & $1.21 \%$ & 2.605 & 2.209 \\
\hline 1995 & 61.75 & $-0.40 \%$ & 2.583 & 2.159 \\
\hline 1996 & & $2.81 \%$ & 2.579 & 2.166 \\
\hline 1997 & & $0.78 \%$ & 2.551 & 2.073 \\
\hline 1998 & & & 2.506 & 2.017 \\
\hline
\end{tabular}

Source: Statistics Canada (1999). Brown and Bilodeau (1999)

The median retirement age for a particular year was regressed on the resultant WTI of that same year. Significant overall regression was obtained with an $R^{2}$ statistic of .55 (see Figure 2). The regression equation is:

Median Retirement Age (years) $=55.40+3.47 \times$ Adjusted Wealth Transfer Index

A second regression model--also accounting for labour productivity improvements in the calculation of the WTI--was fitted (see Figure 3). The median retirement age for a year was regressed on the WTI lagged six years; that is, the retirement age of year $t$ was regressed on the WTI of year $t-6$. Results for this model were impressive, with an $R^{2}$ statistic of .91 . The obtained regression equation is:

Median Retirement Age (years) $=52.77+4.22 \times$ Adjusted Wealth Transfer Index (lagged) 
Lagging the WTI used in the regression model is plausible because individuals, employers and governments all need time to make adjustments to accommodate new realities. The lags involved can basically be categorised into three categories - recognition, decision and implementation lags. First, the agent involved (individual, employer or government) needs to identify and recognize that a wealth transfer shift has occurred (either upward or downward). Once this has been identified, time is needed to respond (e.g. by changing the tax rate).

Figure 2

Model 1, 1976 - 1995

Overlay Plots of Actual Versus Predicted

Average Retirement Age for Canada

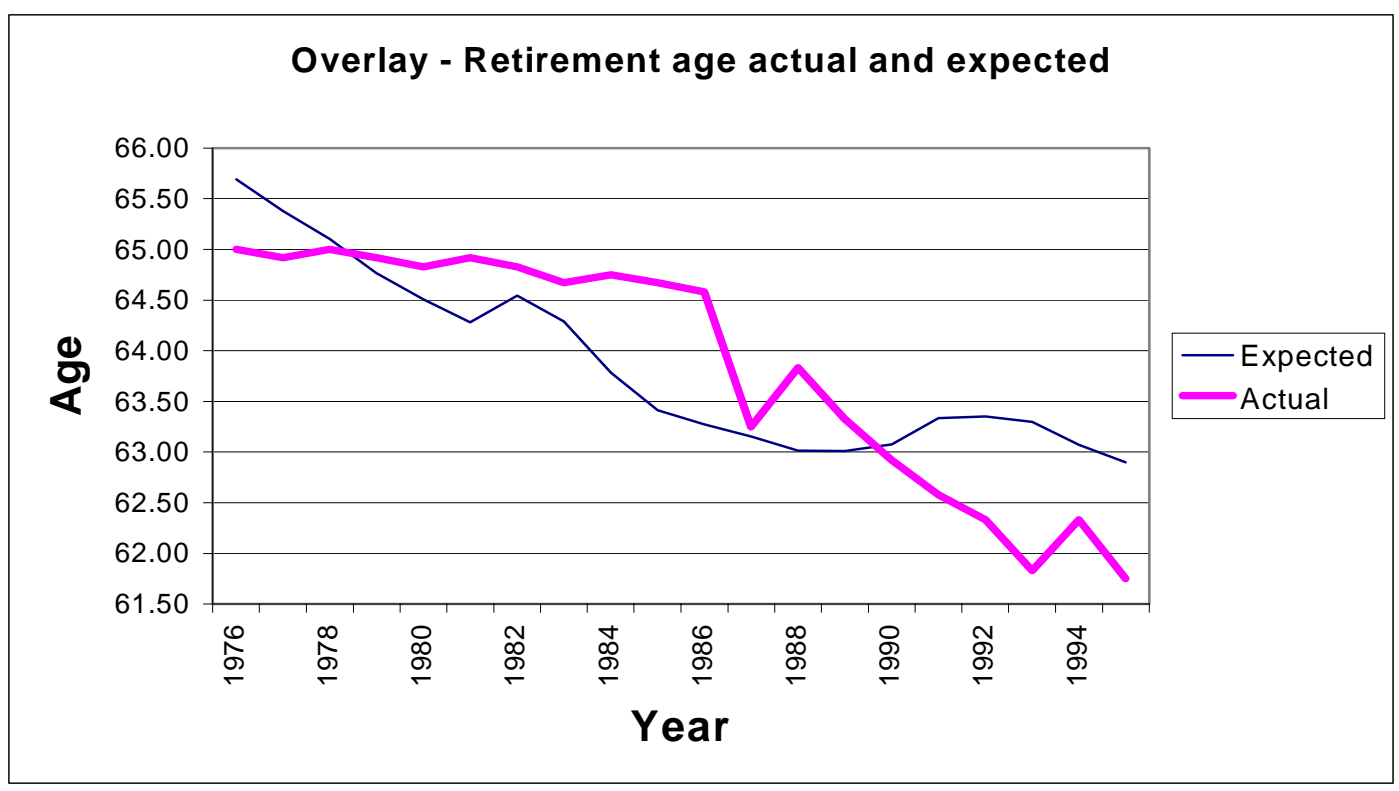

Figure 3

Model 2, 1982 - 1995

Overlay Plots of Actual Versus Predicted

Average Retirement Age for Canada with Lagged WTI

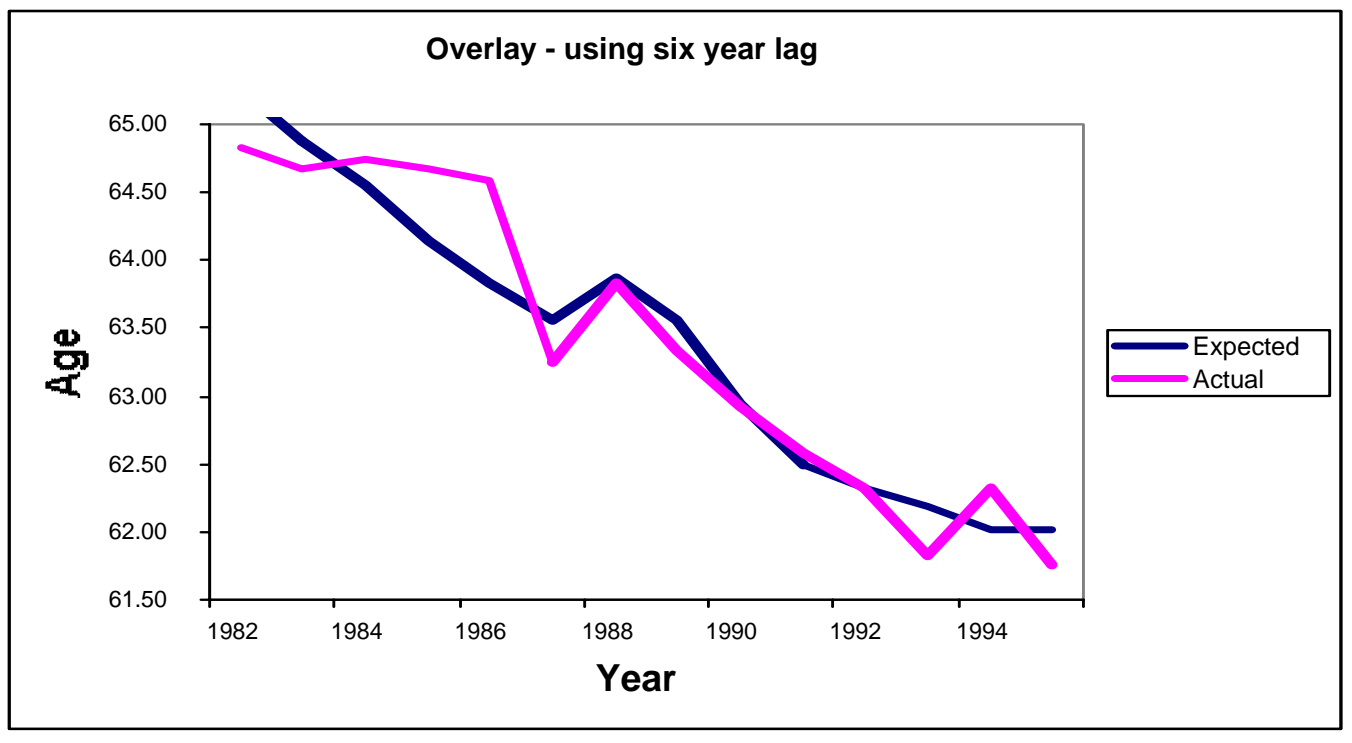


This could take years. Finally, after a response decision has been reached, time would be required for implementation of the suggested course of action. For example, if the WTI declined, it might be possible for governments to lower taxes, for manufacturers to lower prices, or for employers to enhance pension benefits. Any of these actions would allow earlier retirement.

As a second example, with the impending demographic profile where the baby bust generation will be the source of labour, it might be expected that both employers and governments would offer later retirement incentives. However, they would require time to identify the need, and then to implement the incentives. It would also take time for the employee to factor these incentives into his or her retirement decision. Thus, a six-year time lag is completely plausible.

Finally, a linear regression model that did not account for labour productivity improvements was fit using lagged values of the WTI observed during the period 1976-95 (see Figure 4). The results show that the regression is still significant $\left(R^{2}=0.84\right)$ and that the WTI is a useful predictor of the median retirement age (although not as good as model 2). The regression equation is:

$$
\text { Median Retirement Age (years) }=46.77+6.24 \times \text { Wealth Transfer Index (lagged } 6 \text { years) }
$$

Figure 4

Model 3, 1976 - 1995

Overlay Plots of Actual Versus Predicted

Average Retirement Age for Canada Ignoring Productivity

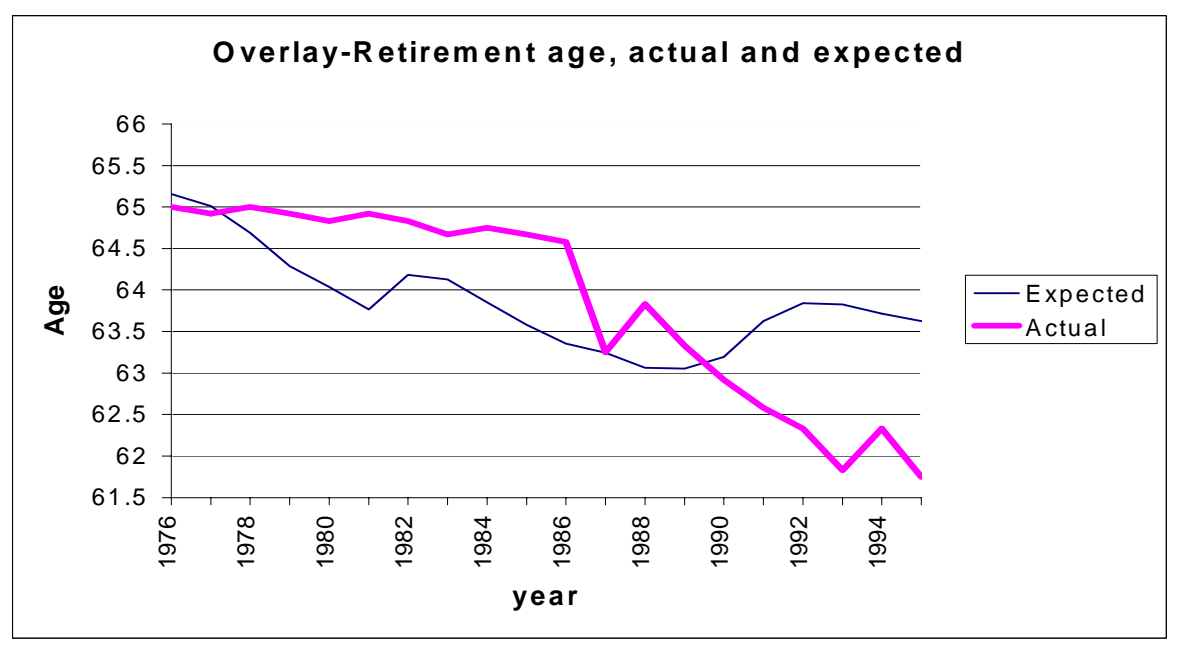

The regression results for the three models, particularly the lagged WTI model, show the existence of a strong positive correlation between the WTI and Median Retirement Age. The WTI quantifies the economic force that "decides" the average age at retirement as a ratio of consumption demand to production supply. Because of this definition of the WTI and the regression results, it might be plausible to infer a causal relation between the WTI and median retirement age.

\section{Projections on Future Retirement Age in Canada}

The previous section provides a model (Model 2) with which to project the retirement age in the future. To this end, we also need to project the WTI in the future. Statistics Canada (1994) has projected the 1993 Canadian population to 2041 under four different sets of assumptions (low-growth, medium-growth, and two high-growth projections). This paper employs the medium-growth projection (projection 2); it is considered to be the most realistic, and Brown and Bilodeau (1999) used the same assumption in their paper. These data provide us with information on the number of young (ages 0 to 19), adult (ages 20 to 64) and elderly (ages 65 and up) in Canada up to 2041.

To determine the number of employed and unemployed adults, we use a method similar to Brown and Bilodeau. Historical participation rates and unemployment rates for various age and sex groups are 
available from Statistics Canada $(1984,1989,1995 b)$ up to 1994 . We then use an ARIMA ${ }^{\S}$ time series methodology to project these rates up to 2006, after which the rates are held constant. The participation rates are segregated between the sexes and different age classes while the unemployment rate is obtained for the entire adult population. By knowing the number of people in the various age and sex categories, the model forecasts the number of employed and unemployed Canadians up to 2041.

The model assumes an annual increase in productivity consistent with the historical increase from 1976 to 1998 (in terms of 1986 dollars). The productivity increase during this period has averaged 0.9\% compounded per annum (pa). The WTI (adjusted) up to 2041 is then found using the projected population and employment data, with the labour force component adjusted to reflect productivity improvements.

Using the six-year lagged regression we obtained in the previous section (Model 2), we are able to project the median retirement age in Canada up to 2047. The result is displayed in Figure 5. If the retirement age rises, it is assumed that these new workers have the labour force participation rates of those aged 60-64.

Figure 5

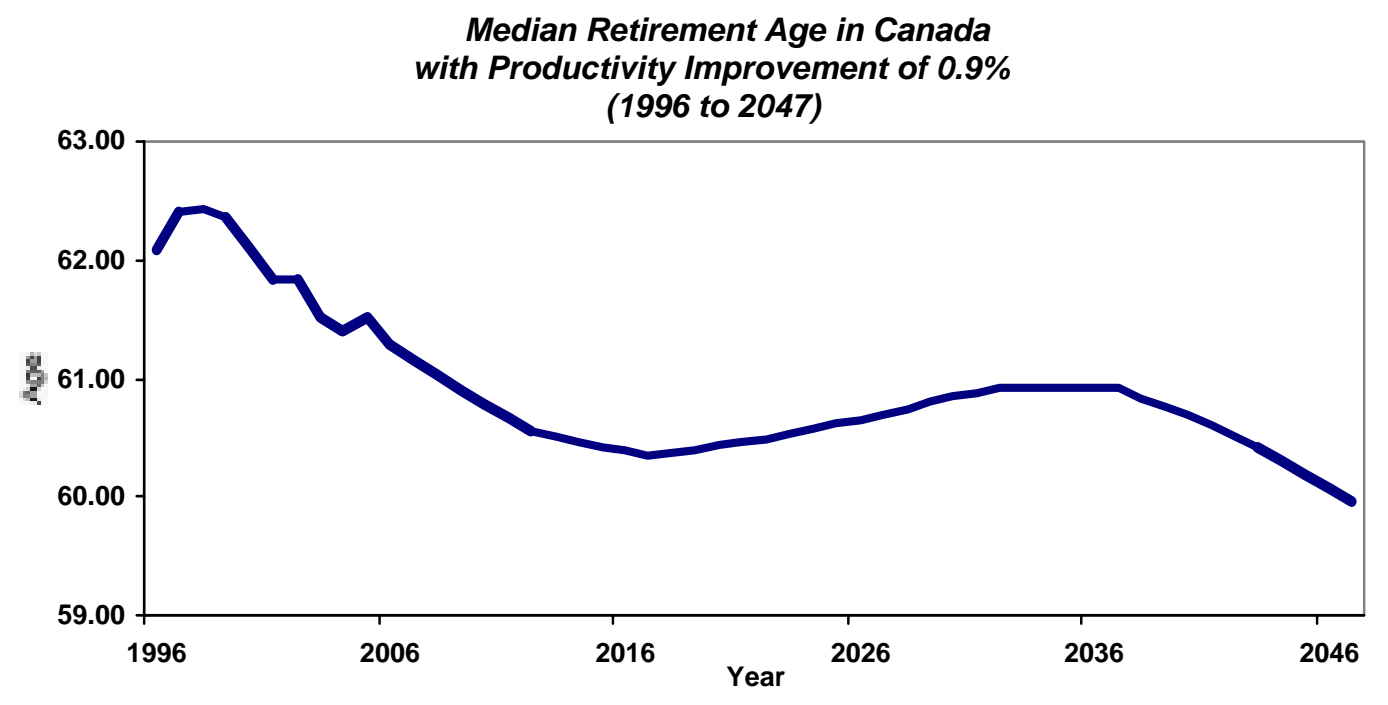

From Figure 5, we can see that the median retirement age is projected to generally decrease until 2017, where it reaches a local minimum of 60.3 years. After this date, the increase in the number of elderly and the decrease in employed adults results in a higher median retirement age as workers must stay longer in the workforce to achieve a constant WTI. The increase is projected to last until 2034 when the median retirement age is 60.9 years. After that, the retirement age is again projected to decrease. In 2041 the median retirement age is forecast to be 60.6 years; it will be 60.0 years in 2047 .

We also show future projected retirement ages with $1.5 \%$ pa productivity growth (Figure 6), and no productivity growth (Figure 7). Finally, in Figure 8 we show that the annual rate of productivity growth required for no increase in retirement age is $1.29 \%$ pa.

\footnotetext{
${ }^{\S}$ For more information on the ARIMA (Autoregressive Integrated Moving Average) process see Chapter 4 of Time Series and Analysis: Forecasting and Control by Box and Jenkins, 1976.
} 
Figure 6

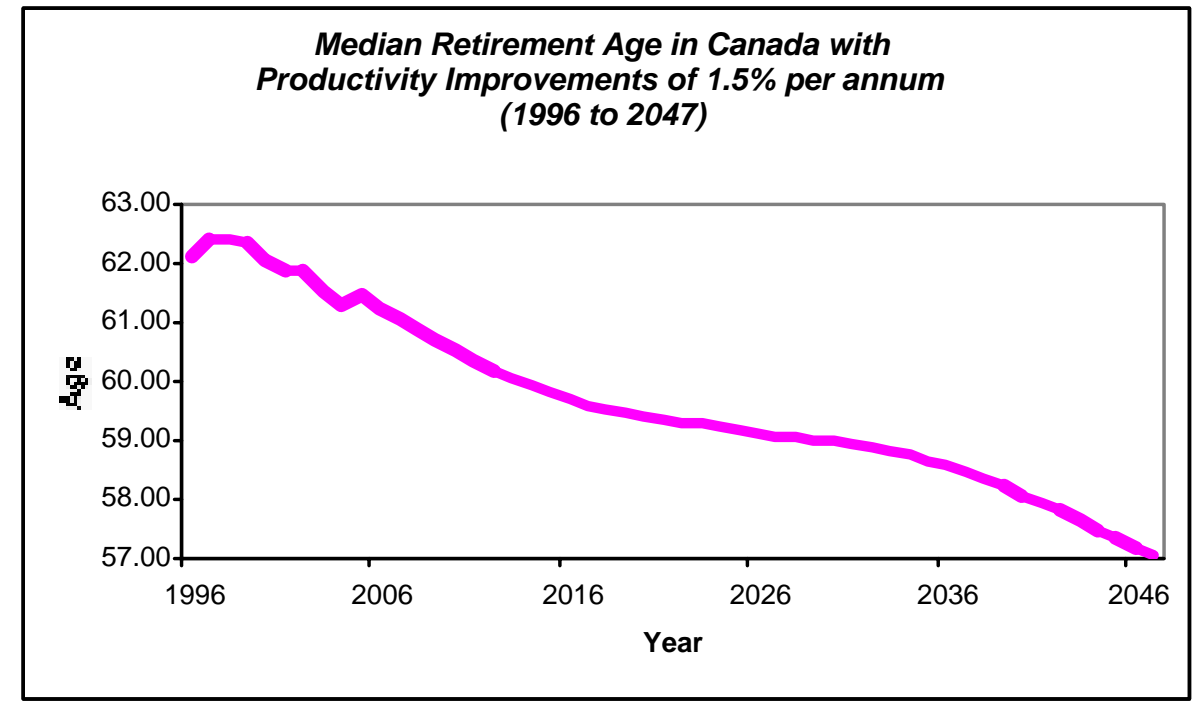

Figure 7

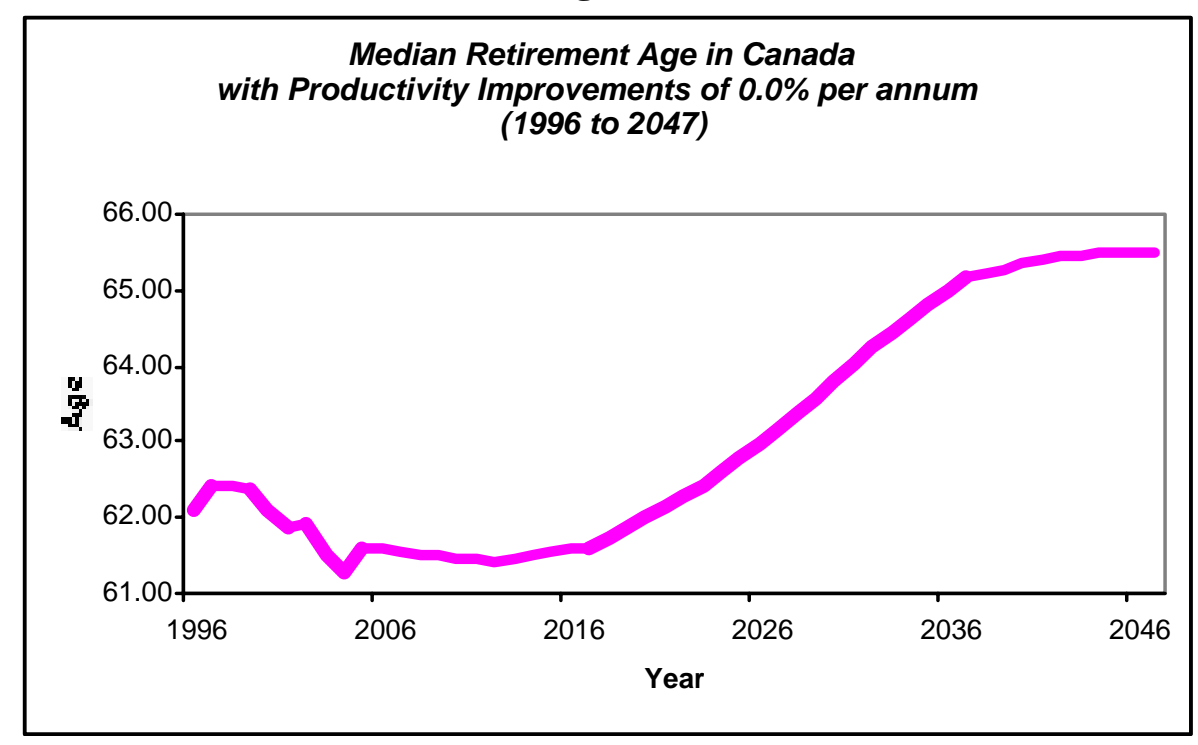

Figure 8

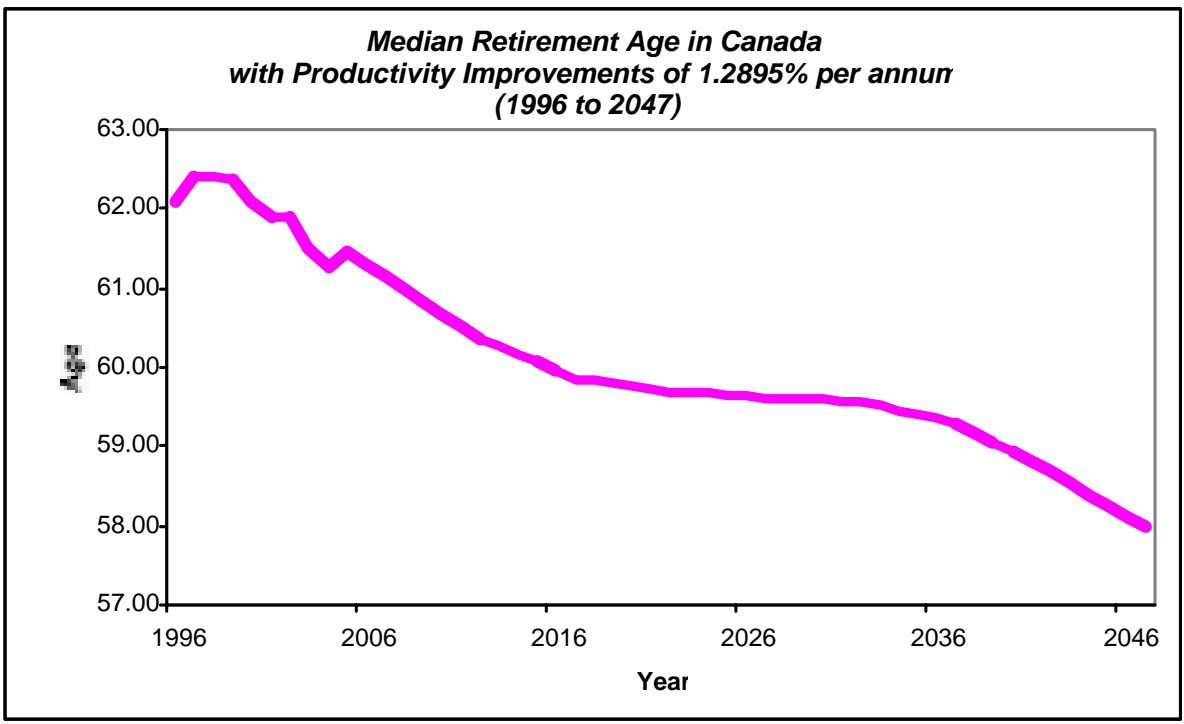




\section{Market Response}

This paper has shown that, after 2016, there will be more pressure for later retirement than for early retirement.

What will that mean for the design and administration of employer-sponsored pension plans? One would expect that in the normal realm of labour economics, once older workers determine they are a scarce and valued commodity, they will bargain for more acceptable work arrangements. This might mean higher compensation, but it could just as easily mean pension benefits more attuned to their needs. For example, a worker might ask to be allowed to work Tuesday through Thursday, and contribute to the pension plan, but then take every Friday and Monday off and draw pension benefits on those two days. Or, similarly, a worker might suggest a work year covering the seven months from April to October during which the worker would be employed full-time and contribute to the pension plan, but for the months from November to March, the worker would be considered "retired" and draw from the pension plan. Neither of these arrangements exist today within a normal pension plan (in fact, they would not be allowed under the regulations for Qualified/Registered plans), but there is nothing to stop them from being created actuarially.

Further, one must become aware of the fact that retirement is not a one-time, one-day event. Workers do not go from 40 hours a week to full-time leisure. It is now estimated that between 30 and 50 percent of people move into their "final" retirement via partial retirement, or use "bridge jobs" from their "career" jobs into retirement, and that this process can take up to five years. Further, it is the best educated workers who have been forced to retire early who are most likely to return to a bridge job (see McDonald, 1996, Burkhauser, 1996 and Quinn, 1997/99). Thus, what is needed is not costlier retirement benefits, but more flexible benefits and administration that can be tailored to the needs of the individual worker. The day of "one size fits all" should be over. What is needed are employers, pension plans and regulations that allow for a longer-term transition from full-time work to full-time retirement. Workers should not have to leave their primary or career employer to find "bridge jobs". They should be able to find "bridge jobs" where their skills are most valuable, and this is within their career post. To do otherwise is to deny and waste a huge asset, namely the older worker.

Finally, Defined Benefit plans that are integrated with Social Security (i.e. the C/QPP) will have to be cognizant of any future benefit reductions by the government, since, depending on the design of the plan, reductions in government benefits would be matched automatically by increases in employer-sponsored benefits. In Canada, 82 percent of pension plan members are in integrated plans.

\section{Conclusion}

There appears to be a very strong positive correlation between the WTI and retirement age based on Canadian historical data for the years 1976-1995. It is plausible that due to the time required for recognition, decision, and implementation, the effects quantified by the WTI will be lagged several years (apparently close to six years).

The regression model obtained (Model 2) was used to project future retirement ages. It indicates that the median retirement age in Canada will generally decrease from 61.75 in 1995 to 60.3 years in 2017, increase slightly to a local maximum of 60.9 years in 2034, and then decrease once again to 60.0 years at the end of the projection period, 2047.

This projection of the expected retirement age is consistent with a philosophical view that government transfers, including education, unemployment insurance and social security, represent wealth transfer. But wealth can only be transferred after it has been created, and then only in the amount that has been created.

This paper concludes that, historically, workers have retired at the earliest possible age that was affordable given the limits on the potential transfer of wealth. The paper further concludes that this will continue to be true, whether legislated by government or not. If true, the retirement age experienced by the work force is just another resultant variable in a macro economy that must operate in balance: that is, the variable "retirement age" is just another balance-point variable that will be decided by economic realities, not government legislation. 


\section{References}

Box, George, E.P., and G.M. Jenkins (1976). Time Series and Analysis: Forecasting and Control. San Francisco: Holden-Day.

Brown, Robert L. 1999. Economic Security for an Aging Canadian Population. Society of Actuaries Monograph M-RS99-2. Schaumburg, IL: Society of Actuaries.

Brown, Robert L. and C. Bilodeau. 1999. "The Canadian Wealth Transfer Index". Proceedings of the Canadian Institute of Actuaries, 1996-97 28(2): 435-54.

Burkhauser, R.V. 1996. Touching the Third Rail: Alternative Solutions for Bringing the Social Security Retirement System into Long-Term Balance. The Bowles Symposium, Georgia State University, Atlanta, GA. Also summarized as the Editorial in The Gerontologist, Volujme 36, No.6 pp 726727.

Foot, D.K. 1982. Canada's Population Outlook. Canadian Institute for Economic Policy, Toronto: James Lorimer.

McDonald, L. and E.B. Carty 1980. "Effect of Projected Population Change on Expenditures of Government." The Retirement Income System in Canada: Problems and Alternative Policies for Reform, vol. 2, 16-1-34, Task Force on Retirement Income Policy, eds. Ottawa: Minister of Supply and Services.

McDonald, P.L. 1996. Transitions into Retirement: A Time for Retirement. Final Report. Human Resources Development, Canada.

Office of the Superintendent of Financial Institutions 1998. Canada Pension Plan Seventeenth Actuarial Report as at 31 December 1997. Ottawa: Ministry of Finance.

Quinn, J. 1997a. The Role of Bridge Jobs in the Retirement Patterns of Older Americans. In Philip deJong and Theodore Marmor (eds), Social Security and the Labor Market. Ashgate Publishing Ltd., London, pp 91-116.

1997b "Retirement Trends and Patterns in the 1990's: The End of an Era?" The Public Policy Aging Report. Vol. 8, No. 3. pp 10-15

1999 New Paths to Retirement. Working Paper. To Appear.

Schieber, S.J., and Shoven, J.B. 1994. "The Consequences of Population Aging on Private Pension Fund Saving and Asset Markets,” NBER Working Paper No. 4665. Cambridge, MA: National Bureau of Economic Reasearch.

Statistics Canada. 1984. Labour Force Annual Averages, 1975-1983. Catalogue No. 71-529, Ottawa: Ministry of Industry, Science and Technology.

. 1986. "Longevity and Historical Life Tables (1921-1981) (Abridged)." In Canada and the Provinces. Ottawa: Ministry of Supply and Services.

1989. Labour Force Annual Averages, 1981-1988. Catalogue No. 71-529. Ottawa: Ministry of Industry, Science and Technology.

1994. Population Projections for Canada, Provinces and Territories, 1993-2016. Catalogue No 91-520, Ottawa: Ministry of Industry, Science and Technology. 
1995a. Life Tables, Canada and the Provinces, 1990-1992. Catalogue No. 84-537. Ottawa: Ministry of Industry, Science and Technology.

1995b. Labour Force Annual Averages, 1989-1994. Catalogue No. 71-529. Ottawa: Ministry of Industry, Science and Technology.

1996. Canada's Changing Retirement Patterns: Findings from the General Social Survey. Catalogue No. 89-546-XPE. Ottawa: Ministry of Industry, Science and Technology.

1997. Report on the Demographic Situation in Canada, 1996. Current Demographic Analysis. Catalogue No. 91-209-XPE, Ottawa: Ministry of Industry, Science and Technology.

1999. Historical Median Retirement Ages in Canada. Ottawa: Ministry of Industry, Science and Technology.

Task Force on Retirement Income Policy 1979. "The Retirement Income System in Canada: Problems and Alternative Policies for Reform." Ottawa: Ministry of Supply and Services. 